\title{
Promoting orphan crops research and development
}

\author{
Zerihun Tadele $^{1} \cdot$ Dorothea Bartels ${ }^{2}$
}

Published online: 6 July 2019

(c) Springer-Verlag GmbH Germany, part of Springer Nature 2019

Orphan crops are crops with little significance at the global scale but they play a vital role in the food and nutrition security as well as the livelihood of resource-poor farmers and consumers in the developing world. The term 'orphan' refers to the neglect of the crop by the international research community. Orphan crops are also known as indigenous-, lost-, minor-, promising-, and underutilized-crops, among other names (Tadele 2019). Although little scientific research has been done on most orphan crops, a limited number of them have enjoyed advanced studies. This has mainly been due to committed scientists and institutions in developing countries as well as financial and technical support from developed nations.

Most orphan crops are resilient to extreme environmental conditions. Due to this adaptability to marginal and low input environments, orphan crops offer opportunities for low greenhouse gas emissions (Mabhaudhi et al. 2019). In addition, these indigenous crops provide nutrient-rich biodiversity and healthier diets to resource-poor consumers (Hunter et al. 2019). Due to multiple dietary benefits and their tolerance to extreme environmental conditions, some orphan crops are considered to be crops for the future.

In this issue, orphan crops from different crop types are represented. Cereals and pseudo-cereals are represented by finger millet (Eleusine coracana) (Sood et al. 2019), tef (Eragrostis tef) (Chanyalew et al. 2019; Bachewe et al. 2019) and buckwheat (Fagopyrum esculentum) (Joshi et al. 2019). Similarly, legumes which are a rich source of protein for the poor are represented by bambara groundnut (Vigna subterranea) (Mayes et al. 2019), grass pea (Lathyrus sativus) (Lambein et al. 2019; Rathi et al. 2019a, b), rice bean (Vigna umbellata) (Pattanayak et al. 2019), horsegram (Macrotyloma uniflorum) (Aditya et al. 2019) and winged bean (Psophocarpus tetragonolobus) (Tanzi et al. 2019). In

\footnotetext{
$\checkmark$ Zerihun Tadele

zerihun.tadele@ips.unibe.ch

University of Bern, Bern, Switzerland

2 University of Bonn, Bonn, Germany
}

addition, leafy vegetable (Gynandropsis gynandra) (Sogbohossou et al. 2019) and Cinderella species (Leakey 2019) are also included in the issue.

While conventional breeding techniques have been extensively employed in the improvement of the majority of orphan crops, marker-assisted techniques particularly the use of microsatellites have already been implemented in some of them (Chanyalew et al. 2019; Tanzi et al. 2019; Pattanayak et al. 2019; Aditya et al. 2019). Advanced tools such as genomics, transcriptomics and metabolomics have been applied to a limited number of orphan crops (Rathi et al. 2019b, a; Sood et al. 2019; Joshi et al. 2019). Innovative cropping systems (Leakey 2019) and value-chain approaches involving social scientists (Bachewe et al. 2019) are also being reported.

Among institutions or platforms dedicated to research on orphan crops the activities and progresses are reported for three examples. These are Modern Plant Breeding Platform (Ribaut and Ragot 2019), Crops for the Future (CFF) (Gregory et al. 2019) and the African Orphan Crops Consortium (AOCC) (Hendre et al. 2019). The latter is committed to sequence the genome of 101 African orphan crops. Awareness and promotion of orphan crops have been done at different forums; the most recent was at the International Food for Future Conference held in Cologne, Germany (Succurro et al. 2019).

This issue does not cover the complete spectrum of orphan crops and hopefully this series can be continued and reports can be included on cowpea (Vigna unguiculata), enset (Ensete ventricosum), minor fruits, quinoa (Chenopodium quinoa), sesame (Sesamum indicum) and yam (Dioscorea species).

In general, papers in this issue provide information related to the improvement of diverse orphan crops. Advances on these largely neglected crops have been made using very limited resources but dedicated researchers and institutions made very respectable progress.

Finally, we would like to thank all authors, reviewers and editorial staff of Planta for their contributions to this special issue. Our appreciation also goes to the Planta Editorial 
Board for its decision to promote the awareness of orphan crops through dedicating an entire issue to this topic. To our knowledge, this is the first time an entire issue of a journal has been devoted to Orphan Crops.

\section{References}

Aditya JP, Bhartiya A, Chahota RK, Joshi D, Chandra N, Kant L, Pattanayak A (2019) Ancient orphan legume horse gram: a potential food and forage crop of future. Planta. https://doi.org/10.1007/ s00425-019-03184-5

Bachewe F, Dereje M, Minten B, Taffesse AS, Tamru S, Worku I (2019) The transforming value chain of Ethiopia's "orphan" tef crop. Planta. https://doi.org/10.1007/s00425-019-03224-0

Chanyalew S, Ferede S, Damte T, Fikre T, Genet Y, Kebede W, Tolossa K, Tadele Z, Assefa K (2019) Significance and prospects of an orphan crop tef. Planta. https://doi.org/10.1007/s00425-01903209-z

Gregory PJ, Mayes S, Hui CH, Jahanshiri E, Julkifle A, Kuppusamy G, Kuan HW, Lin TX, Massawe F, Suhairi T, Azam-Ali SN (2019) Crops For the Future (CFF): an overview of research efforts in the adoption of underutilised species. Planta. https://doi.org/10.1007/ s00425-019-03179-2

Hendre PS, Muthemba S, Kariba R, Muchugi A, Fu Y, Chang Y, Song B, Liu H, Liu M, Liao X, Sahu SK, Wang S, Li L, Lu H, Peng S, Cheng S, Xu X, Yang H, Wang J, Liu X, Simons A, Shapiro HY, Mumm RH, Van Deynze A, Jamnadass R (2019) African orphan crops consortium (AOCC): status of developing genomic resources for African orphan crops. Planta. https://doi. org/10.1007/s00425-019-03156-9

Hunter D, Borelli T, Beltrame DMO, Oliveira CNS, Coradin L, Wasike VW, Wasilwa L, Mwai J, Manjella A, Samarasinghe GWL, Madhujith T, Nadeeshani HVH, Tan A, Ay ST, Guzelsoy N, Lauridsen N, Gee E, Tartanac F (2019) The potential of neglected and underutilized species for improving diets and nutrition. Planta. https://doi.org/10.1007/s00425-019-03169-4

Joshi DC, Chaudhari GV, Sood S, Kant L, Pattanayak A, Zhang K, Fan Y, Janovska D, Meglic V, Zhou M (2019) Revisiting the versatile buckwheat: reinvigorating genetic gains through integrated breeding and genomics approach. Planta. https://doi.org/10.1007/s0042 5-018-03080-4

Lambein F, Travella S, Kuo YH, Van Montagu M, Heijde M (2019) Grass pea (Lathyrus sativus L.): orphan crop, nutraceutical or just plain food? Planta. https://doi.org/10.1007/s00425-018-03084-0

Leakey RRB (2019) From ethnobotany to mainstream agriculture: socially modified Cinderella species capturing 'trade-ons' for 'land maxing'. Planta. https://doi.org/10.1007/s00425-019-03128

Mabhaudhi T, Chimonyo VGP, Hlahla S, Massawe F, Mayes S, Nhamo L, Modi AT (2019) Prospects of orphan crops in climate change. Planta. https://doi.org/10.1007/s00425-019-03129-y

Mayes S, Ho WK, Chai HH, Gao X, Kundy AC, Mateva KI, Zahrulakmal M, Hahiree MKIM, Kendabie P, Licea LC, Massawe F, Mabhaudhi T, Modi AT, Berchie JN, Amoah S, Faloye B, Abberton M, Olaniyi O, Azam-Ali SN (2019) Bambara groundnut-an exemplar underutilised legume for resilience under climate change. Planta. https://doi.org/10.1007/s00425-019-03191-6

Pattanayak A, Roy S, Sood S, Iangrai B, Banerjee A, Gupta S, Joshi DC (2019) Rice bean: a lesser known pulse with well-recognized potential. Planta. https://doi.org/10.1007/s00425-019-03196-1

Rathi D, Gayali S, Pareek A, Chakraborty S, Chakraborty N (2019a) Transcriptome profiling illustrates expression signatures of dehydration tolerance in developing grasspea seedlings. Planta. https ://doi.org/10.1007/s00425-018-03082-2

Rathi D, Pareek A, Zhang T, Pang Q, Chen S, Chakraborty S, Chakraborty N (2019b) Metabolite signatures of grasspea suspension-cultured cells illustrate the complexity of dehydration response. Planta. https://doi.org/10.1007/s00425-019-03211-5

Ribaut JM, Ragot M (2019) Modernising breeding for orphan crops: tools, methodologies, and beyond. Planta. https://doi.org/10.1007/ s00425-019-03200-8

Sogbohossou EOD, Kortekaas D, Achigan-Dako EG, Maundu P, Stoilova T, Van Deynze A, de Vos RCH, Schranz ME (2019) Association between vitamin content, plant morphology and geographical origin in a worldwide collection of the orphan crop Gynandropsis gynandra (Cleomaceae). Planta. https://doi. org/10.1007/s00425-019-03142-1

Sood S, Joshi DC, Chandra AK, Kumar A (2019) Phenomics and genomics of finger millet: current status and future prospects. Planta. https://doi.org/10.1007/s00425-019-03159-6

Succurro A, Schuler-Bermann M, Ivanov R, Jacoby R, Kopriva S, Jobe TO (2019) Orphan crops at the food for future conference. Planta (in press)

Tadele Z (2019) Orphan crops: their importance and the urgency of improvement. Planta. https://doi.org/10.1007/s00425-019-03210 $-6$

Tanzi AS, Eagleton GE, Ho WK, Wong QN, Mayes S, Massawe F (2019) Winged bean (Psophocarpus tetragonolobus (L.) DC.) for food and nutritional security: synthesis of past research and future direction. Planta. https://doi.org/10.1007/s00425-019-03141-2

Publisher's Note Springer Nature remains neutral with regard to jurisdictional claims in published maps and institutional affiliations. 